\title{
INNOVATION AND COMPANY VALUE: EVIDENCE FROM THE BALTIC COUNTRIES
}

\author{
Irina Berzkalne ${ }^{1}$, Elvira Zelgalve² \\ University of Latvia (Latvia)
}

\begin{abstract}
Innovation is the basis for competitiveness. At the same time, the primary objective of the manager is stockholder wealth maximization, therefore it is essential to study the relationship between innovation and value. The aim of the study is to evaluate the impact of innovation on company value. The research covered Baltic listed companies for the period of 2005-2011. The study finds that innovative companies have a higher value and they are bigger. Within innovative companies it was observed that higher company value is achieved if their ratio of intangible assets exceeds $1 \%$. Using correlation and multiple regression analyses it was found that innovation is a significant determinant of company value, whereas size is a weaker factor and growth is the least significant factor. The authors of the paper recommend for companies to invest in innovation process, since it increases company value, especially if the ratio of intangible assets exceeds $1 \%$.

KEYWORDS: company value, innovation, intangible assets, research and development, Tobin's $Q$.
\end{abstract}

JEL CODES: G32, O16, O31

\section{Introduction}

“When all think alike, then no one is thinking." Walter Lippmann, American public intellectual, writer, reporter, and political commentator.

Innovation is the basis for competitiveness. Innovation is crucial for countries and companies for their survival and growth. With the help of innovation, it is possible to create value, to streamline the organization, to create intellectual property, to achieve a heightened competitive advantage, etc. The importance of innovation and innovative companies is especially significant in the light of recent economic turmoil. Innovative companies create new jobs, offer more valuable products to the customer, increase exports, etc. However, the primary objective of the manager is stockholder wealth maximization. Therefore, it is important to understand and analyze whether there is any relationship between innovation and company value and at what level of innovation the company value is maximized.

The aim of the study is to evaluate the impact of innovation on company value. The tasks of the research are as follows:

- to overview the results of previous research;

- to overview the innovation indicators;

Irina Berzkalne - University of Latvia, Mg. oec., PhD student

E-mail: irina.berzkalne@inbox.lv

Tel.: +37129992532

2 Elvira Zelgalve - University of Latvia, Dr. oec., Professor, Head of the Finance Department

E-mail: elzelg@lanet.lv

Tel.: +37129488000 
- to evaluate the relationship between innovation and company value;

- to make conclusions and workout recommendations on the relationship between innovation and company value.

The analysis is conducted on a sample of 64 listed companies (Baltic Stock Exchange) over the period from 2005 to 2011. In the research paper, the following qualitative and quantitative methods of research are applied: the monographic method, graphical method, comparative analysis, correlation analysis andmultiple regression analysis. The research is based on published papers on innovation and company value, as well as information provided by the Baltic Stock Exchange.

Correlation and multiple regression analyses are done using the Statistical Package for the Social Sciences (SPSS).

\section{Literature review}

Innovation studies started to emerge as a separate field of research in the 1960s (Fagerberg, 2003). Since then a sizeable amount of literature on innovation has been developed (Fagerberg et al., 2012).

Some studies explore the characteristics of innovative companies. Ayyagari et al. (2011) stated that more innovative firms are large exporting firms characterized by private ownership, highly educated managers with mid-level managerial experience, and access to external finance. De Mel et al. (2009) developed a model of innovation which incorporates the role of both owner and firm characteristics. As predicted by the model, firm size was found to have a stronger positive effect, and competition a stronger negative effect on process and organizational innovations than on product innovations. Owner ability, personality traits, and ethnicity are found to have significant impact on the likelihood of a firm innovating.

Due to the recent economic recession, several studies analyze the changes in innovation within the business cycle. Huhtala (2011) found that customer orientation and interfunctional coordination to play an accentuated role in building innovation capability and achieving solid business performance when the economy is booming, whereas competitor orientation was found to play a more significant role during downturn. The current crisis has substantially reduced the number of firms willing to increase their innovation investment, from $38 \%$ to $9 \%$, as emphasized by Archibugi et al. (2012). Before the economic downturn, firms expanding their innovations were well-established, engaged in formal research activities both internally and bought in; exploited strong appropriability conditions, were involved in collaboration with suppliers and customers. During the economic downturn the firms are smaller than before, collaborating with other businesses, exploring new market opportunities, using methods of technological appropriation, and less likely to compete on costs. Lopez-Garcia et al. (2012) stated that the share of R\&D spending over total investment is countercyclical without credit constraints, but this cyclical behavior could be reversed as firms face tighter financial constraints.

Many papers are published on innovation and company value. Hall (1998) concluded that the market value of the modern manufacturing corporation is strongly related to its knowledge assets, and that patent measures contain information about this value above and beyond that conveyed by the usual R\&D measures. Kraft and Czarnitzki (2002) proposed an alternative method to study the impact of innovation on firm value - the calculation of the relation between innovative activity and credit ratings. The measures of innovation were significantly influencing the credit ratings in all cases. They found a non-linear relationship: some innovative activity raises the credit rating, but too much innovativeness has a negative impact.

Shin and Kim (2011) found evidence that the innovative small and medium sized enterprises can maintain higher firm value by innovation activities.

Sorescu and Spanjol (2008) concluded that breakthrough innovation is associated with increases both in normal profits and economic rents, and that, on average, each breakthrough innovation in the sample is associated with an increase in firm value. Breakthrough innovation is also associated with increases in the risk of the innovating firm, but this higher risk is offset by above-normal stock returns.The study by 
Annavarjula et al. (2008) found that R\&D spending positively impacts the firm value both immediately and over time.

Belenzon and Patacconi (2012) used data from more than 33,000 mergers and acquisitions deals between 1985 and 2007, and distinguish between American (USPTO) and European (EPO) patents. Their results indicate that over time EPO patents have become the dominant indicator of innovative activity, while USPTO patents have no effect on firm value near the end of the sample period.

Service innovativeness can be categorized into two broad types: internet-enabled service innovativeness (e-innovativeness) and people-enabled service innovativeness (p-innovativeness). Dotzel et al. (2013) found that e-innovativeness has a positive and significant direct effect on firm value. P-innovativeness has an overall significantly positive effect on firm value through its positive effect on customer satisfaction, but only in human-dominated industries. Kogan et al. (2012) measured that higher technological innovation is followed by a decline in the aggregate Tobin's Q.

To sum up, most studies confirm a positive relationship between innovation and company value. Nevertheless, some studies explore non-linear relationship between both variables and a significant correlation is not always there. In the last 50-60 years an enormous number of research has been written on innovation, innovative companies and their characteristics, however, many questions still remain.

\section{Innovation indicators}

In order to draw up development plans and monitor progress, it is necessary to measure the level of innovation. Analysis of innovation level is important, because it helps to determine the influencing factors as well. Countries are ranked by the degree of their innovativeness, for example, Estonia ranks $19^{\text {th }}$, Latvia $30^{\text {th }}$ and Lithuania $38^{\text {th }}$ (Global Innovation Index, 2012).

Figure 1 represents the proportion of innovative enterprises from 2008 to 2010 . EU average is 52.9 \%, proportion of Estonian enterprises is more than EU average and is $56.8 \%$. The ratios of Lithuanian and Latvian companies are significantly lower than EU average and Estonian results, $34.5 \%$ and 29.9 \%, respectively. In other words, while in Estonia every second company can be described as an innovative, then in Latvia only one in three companies can call itself as innovative. That is a significant difference within the Baltic countries and one must analyze influencing factors, which have lead Estonia to achieve a higher level of innovation.

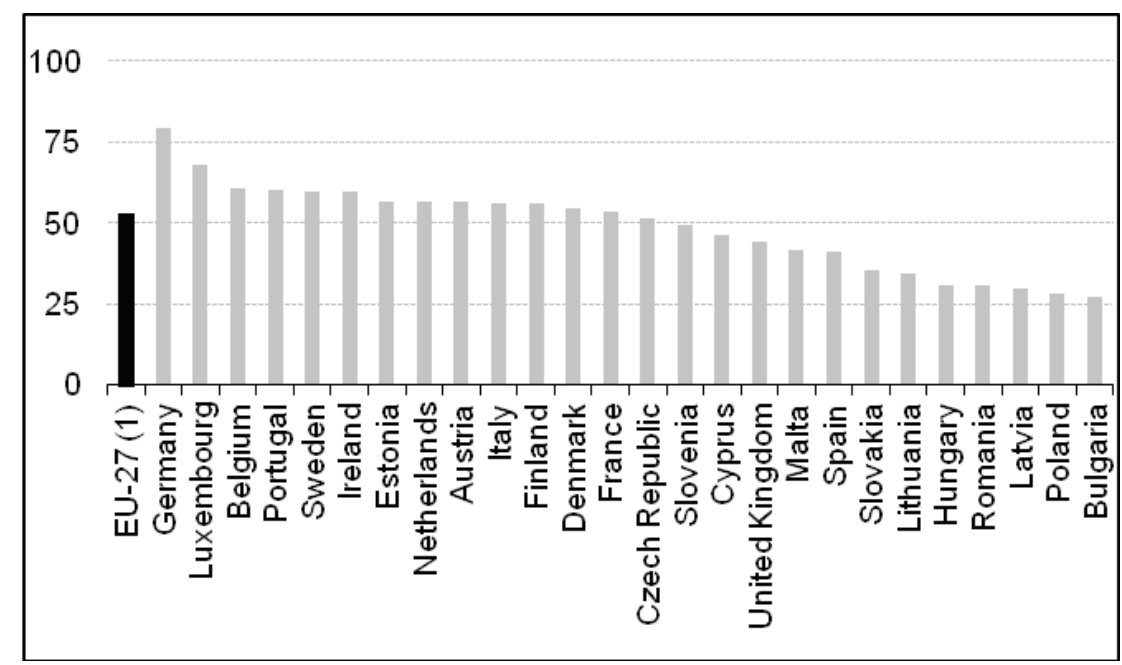

Figure 1. Proportion of innovative enterprises, 2008-2010 (\% of all enterprises) in the EU; (1) excluding Greece

Source: Eurostat 2012

Eurostat defines innovation as the use of new ideas, products or methods where they have not been used before. For the Community Innovation Survey (CIS), an innovation is defined as a new or significantly 
improved product (good or service) introduced to the market, or the introduction within an enterprise of a new or significantly improved process.

The concept of innovation is interpreted differently among statisticians, economists and entrepreneurs and this often causes inaccuracy in innovation accounting. The reasons for difficulty in the producing accurate innovation statistics are to do not only with failure in the interpretation of the concept of innovation, but also with the complexity and dynamism of the innovation process (Jesilevska, 2012).

In literature, a wide range of different innovation indicators exist. For example, Kleinknecht et al. (2002) characterize common innovation indicators, and their strengths and weaknesses (Table 1).

Table 1. Strengths and weaknesses of innovation indicators

\begin{tabular}{|c|c|c|}
\hline Indicator & Strengths & Weaknesses \\
\hline $\begin{array}{l}\text { R\&D efforts } \\
\text { Expenditures on R\&D (as a } \\
\text { percentage of a firm's total } \\
\text { sales) or by the number of } \\
\text { persons carrying out R\&D } \\
\text { (as a percentage of total } \\
\text { employment in a firm) }\end{array}$ & 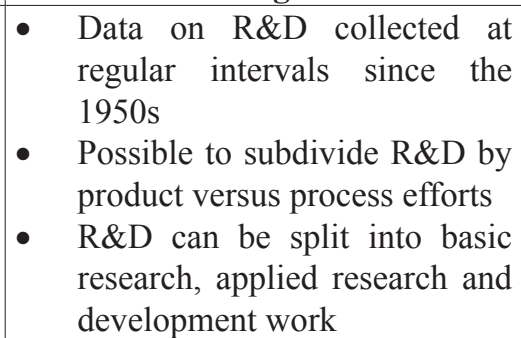 & $\begin{array}{l}\text { - R\&D is an input of the innovation process and } \\
\text { inputs can be used more or less efficiently. } \\
\text { R\&D says nothing about the output. } \\
\text { - R\&D is only one out of several inputs. Other } \\
\text { (non-R\&D) inputs include product design, } \\
\text { trial production, market analysis, training of } \\
\text { employees etc. }\end{array}$ \\
\hline $\begin{array}{l}\text { Patents and patent } \\
\text { application }\end{array}$ & $\begin{array}{l}\text { - } \quad \text { Very long historical time series } \\
\text { are available } \\
\text { Patent databases are publicly } \\
\text { available } \\
\text { - Patents are classified in much } \\
\text { detail by technical field }\end{array}$ & 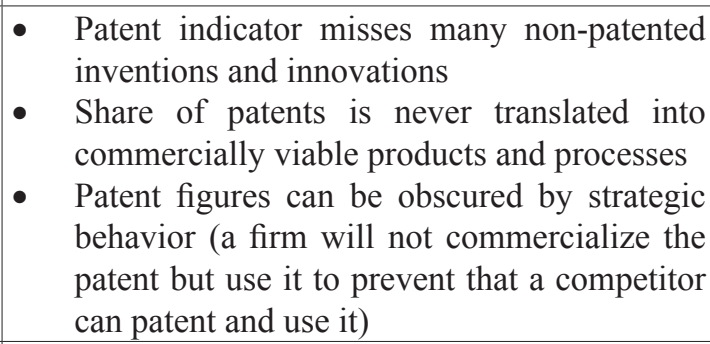 \\
\hline $\begin{array}{c}\text { Total innovation } \\
\text { expenditures }\end{array}$ & $\begin{array}{l}\text { - Figures on total innovation } \\
\text { expenditures cover a larger } \\
\text { variety of inputs into the } \\
\text { innovation process }\end{array}$ & $\begin{array}{l}\text { Question about non-R\&D inputs are difficult } \\
\text { to answer accurately since many firms do not } \\
\text { keep such records }\end{array}$ \\
\hline $\begin{array}{l}\text { Sales of imitative and } \\
\text { innovative products } \\
\text { This indicator is based on } \\
\text { a firm's assessment in a } \\
\text { postal survey of new product } \\
\text { introduction }\end{array}$ & $\begin{array}{l}\text { - Direct measure of successful } \\
\text { innovation, measuring innova- } \\
\text { tions that were introduced into } \\
\text { the market and that resulted in } \\
\text { a positive cashflow }\end{array}$ & $\begin{array}{l}\text { - Indicators from postal innovation surveys } \\
\text { sometimes suffer from low response rates, } \\
\text { which can make it difficult to produce figures } \\
\text { that can be interpreted as national totals }\end{array}$ \\
\hline \begin{tabular}{|l|} 
New product \\
announcements \\
It has also been tried to \\
measure innovative output \\
by systematically screening \\
new product announcements \\
in trade and technical journals
\end{tabular} & $\begin{array}{l}\text { - Direct measure of the market } \\
\text { introduction of new products or } \\
\text { services. The data are relatively } \\
\text { cheap to collect as students } \\
\text { can do it and firms are not } \\
\text { bothered with time-consuming } \\
\text { questionnaires }\end{array}$ & $\begin{array}{l}\text { - New product counts depend on adequate } \\
\text { journal selection. It is important to select } \\
\text { the relevant journals, but the number of } \\
\text { innovations will depend on the number of } \\
\text { journal covered. } \\
\text { - Assumption that firms have an incentive to } \\
\text { make their product and service innovations } \\
\text { public and that they use the possibility to have } \\
\text { them reported in a journal }\end{array}$ \\
\hline $\begin{array}{r}\text { Significan } \\
\text { inno }\end{array}$ & $\begin{array}{l}\text { - Direct measure of the (suc- } \\
\text { cessful) market introduction of } \\
\text { significant innovation. } \\
\text { Data collection can be done } \\
\text { without contacting firms }\end{array}$ & $\begin{array}{l}\text { - The selection of significant innovations } \\
\text { depends on the quality of experts' judgments, } \\
\text { and idiosyncrasies can play a role. } \\
\text { - The costs of data collection may be high } \\
\text { because experts are needed. } \\
\text { - A good assessment of major innovations is } \\
\text { possible only ex-post; what is to be considered } \\
\text { as a successful basic innovation can only be } \\
\text { recognized after some time }\end{array}$ \\
\hline
\end{tabular}

Source: compiled by the authors, using article by Kleinknecht, Montfort and Brouwer (2002). 
A different grouping of innovation metrics is provided by Kotler and de Bes (2011):

- Economic metrics measure the positive or negative results of innovation using variables from the company's economic-financial statements.

- Intensity refers to the quantity of innovation without taking into account the results derived thereof.

- Effectiveness seek to measure profits in relation to the use of resources with the objective of maximizing innovation outputs while minimizing inputs.

- Culture metrics refer to aspects related to the creative culture of the organization.

In empirical research on innovation and company performance, several indicators are commonly used as a proxy for innovation:

- Kuniy et al. (2010) for each company in a sector of industry calculated the R\&D intensity as the ratio between $R \& D$ expenses and sales. The innovative variable of a company is the percentile of its R\&D intensity in the sector.

- Bartoloni (2013) used a dichotomous variable as a proxy for a firm's successful innovation. This variable is based on the Community Innovation Survey and assumes a value of one if the firm has introduced technological innovation and zero otherwise.

- Hsu (2011) measured innovation by R\&D expenditures to total sales.

- Aghion (2004) used R\&D firm dummy (a dummy variable equal to one if R\&D expenditure is reported to be positive in at least one year and equal to zero otherwise). $R \& D$ intensity measured as $R \& D$ expenditures over total sales.

- Feeny and Rogers (2001) used firms' investment in R\&D and applications for patents, trademarks and designs.

- Kraft and Czarnitzki (2002) used three different measures of innovative activity: R\&D, the patent stock and sales of recently developed products.

One can conclude that the vast majority of research is done using $R \& D$ expenses as a basis for innovation indicator. R\&D figures are available since the 1950 s and they are the most popular innovation indicator (Kleinknecht et al., 2002). However, the use of R\&D is limited in the Baltic countries for several factors, for example:

- The companies rarely have R\&D departments.

- The innovation process is generally an unsystematic search-and-learning process (Sundbo, 1997).

- Reporting of R\&D expenditure is not mandatory (for instance, it became compulsory for large and medium-sized U.K. firms in 1989 (Aghion et al., 2004)).

Innovation is somehow non-measurable. It is possible to measure inputs (for example, widely used R\&D expenses), however, it is not possible to measure output precisely. Surveys can capture the numeric value of innovation only vaguely; because it is filled in by a human and biases are due to appear. Innovation is broader than $R \& D$ or patents.

Therefore, taking into consideration the vast majority of different innovation indicators and diverse innovation methodologies, their strengths and weaknesses, it is possible to conclude that a particular indicator or methodology at the moment does not exist, which would be recognized as the best way to measure and analyze innovation. All indicators are based only on approximate calculation and assumption.

Considering the before mentioned and available data, the authors of this study use intangible assets as a proxy for innovation (in particular, the ratio of intangible assets against the total assets of the company). This decision is based by the fact that although research and development (R\&D) costs are not in themselves intangible assets, however, R\&D activities frequently result in the development of something that is patented or copyrighted, which in turn is included in the balance sheet as an intangible asset. Intangible asset is an identifiable non-monetary asset without physical substance. Examples of possible intangible assets include: computer software, patents, copyrights, motion picture films, customer lists, and mortgage servicing rights, 
licenses, import quotas, franchises, and customer and supplier relationships, marketing rights (Deloitte, 2013). These afore mentioned examples of intangible assets can for the most part be considered as innovation indicators as well.

Several authors have already explored the use of intangible assets. Andrews and de Serres (2012) explored the growing importance of intangible assets as a potential source of innovation and productivity gains. The importance of intangible capital has been rising steeply in OECD and emerging economies with implications for innovation and economic growth. Another view is that there are two types of intangible assets: those that are purchased and those that are internally generated. $R \& D$ costs fall into the category of internally generated intangible assets, therefore it is possible to establish that expenditure on R\&D can fall into the category of intangible assets (ACCA, 2007).

Also SFAS (Statement of Financial Accounting Standards) No. 142 (2001) classifies intangible assets as:

- R\&D costs.

- Software development.

- Patents and copyrights.

- Brands and trademarks.

Li and Liu (2012) derived the relation between a firm's stock return and its intangible assets under the intangible-asset-augmented q-theory framework. The q-theory augmented with intangible investments captures the value premium and the relation between R\&D intensity and stock returns significantly better than the conventional q-theory.

In Figure 2 summarized the strengths and weaknesses of ratio of intangible assets as a for innovation.

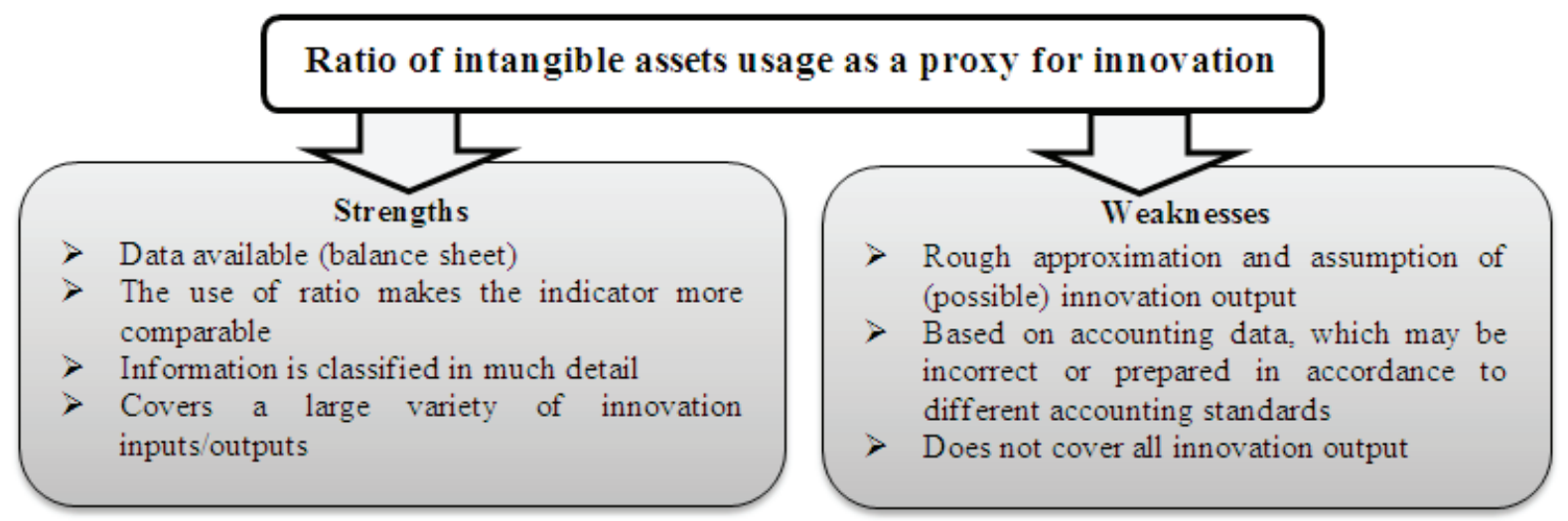

Figure 2. Strengths and weaknesses of ratio of intangible assets

Source: Prepared by the authors of the paper

An additional remark is on goodwill. Goodwill is a part of intangible assets, but the influencing role of stock exchange is small and company can not gain a lot of goodwill by being quoted (Bistrova, Lace, 2011).

\section{Sample and research methodology}

The study is based on financial data collected from the financial statements of 64 Baltic listed companies. The financial and real estate companies are excluded from the study due to their distinct balance sheet structure. The analysis is based on seven years of data (2005-2011) for Estonia, Latvia and Lithuania. The selection criteria required all companies to have all variables available for all seven years analyzed. Companies that failed to meet this requirement were excluded from the sample.

The analysis is conducted using correlation and multiple regression methods. The Pearson correlation correlation ratio measures the degree and direction of linear relationship between two variables. Correlation coefficient of +1 corresponds to a perfect positive linear relationship, coefficient of -1 corresponds to a perfect 
negative linear relationship, and 0 indicates no linear relationship between variables. Regression analysis studies the dependance of one variable on other variables. In addition, the presence of autocorrelation is verified through Durbin-Watson test, and the Variance Inflation Factor is used to test for multicolinearity. This study uses book values to calculate variables.

The study used the following variables:

- As a proxy for innovation, the ratio of intangible assets wasused (calculated by dividing intangible assets by total assets).

- As a proxy for growth, the annual growth rate of total assets was used.

- As a proxy for size, the logarithm of total assets was used.

- As a proxy for the company value, the Tobin's Q was used.

Tobin's Q was introduced by James Tobin (Tobin, 1969). There are several methodologies and formulas used in the calculation of Tobin's Q (Wernerfelt and Montgomery, 1998; Linderberg and Ross, 1981; Chung and Pruitt, 1994). This study uses the methodology by Jin and Jorion (2006). This methodology was used, for example, by Gomez-Gonzales et al. (2012).

$$
\text { Tobin's } Q=\frac{B V \text { total assets }-B V \text { common equity }+M V \text { common equity }}{B V \text { total assets }}
$$

Where $B V$ is book value and $M V$ is market value.

If Tobin's $Q$ is greater than 1, then the market value is greater than the book value of the assets of the company; the market may be overvaluing the company. On the other hand, if Tobin's $Q$ less than 1, then the market value is less than the book value of the assets of the company; the market may be undervaluing the company.

The selection of the variables Tobin's $Q$ and size is primarily guided by the results of previous research. Tobin's $Q$ is used by Coad and Rao (2006), Sorescu (2008), Dotzel et al. (2013). Size isincluded in studies by Coad and Rao (2006), De Mel et al. (2009), Archibugi et al. (2012), Dotzel et al. (2013). In addition, in order to add a novelty to the research, the authors of this study include growth.

To measure the relationship between company value and innovation, the Ordinary Least Squares (OLS) estimation is used based on the following regression model:

$$
\text { Value }_{i t}=\beta_{0}+\beta_{I} \text { Innovation }_{i t}+\beta_{2} \text { Growth }_{i t}+\beta_{3} \text { Size }_{i t}+e_{i t},
$$

where:

Value $_{i t}-$ Tobin's $Q$ of company $i$ at time $t$;

Innovation $_{i t}$ - innovation level of company $i$ at time $t$;

Growth $_{i t}$ - growth of company $i$ at time $t$;

Size $_{i t}$ - size of company $i$ at time $t$;

$e_{i t}$ - the error term.

\section{Empirical analysis and discussion of results}

First, in order to test whether the differences in means are statistically significant, the independent samples test was used. Two groups were compared: 1) one group included all companies, which did not have the balance sheet item "intangible assets" $(0) ; 2)$ the other group included all other companies (1). The results are given in table 2 . 
Table 2. Group statistics on innovation, value, growth and size (Baltic listed companies, 2005-2011)

\begin{tabular}{|c|c|c|c|}
\hline Intangible assets & Mean & Std. Deviation & Std. Error Mean \\
\hline \multicolumn{7}{|c|}{ Tobin's Q } \\
\hline 0 & 0.778918 & 0.4315266 & 0.0941668 \\
\hline 1 & 1.133578 & 0.6325684 & 0.0315105 \\
\hline 0 & 5.750132 & 21.5753002 & 4.7081165 \\
\hline 1 & 10.202413 & 32.2126229 & 1.6046250 \\
\hline \multicolumn{7}{|c|}{ Size } \\
\hline 1 & 15.753525 & 2.4066433 & 0.5251726 \\
\hline
\end{tabular}

Source: authors' calculations based on the annual reports of the listed companies (Baltic Stock Exchange).

The results of independent samples test show that the means of Tobin's $Q$ are statistically significant. If company is innovative, its value is higher compared to a non-innovative company. In addition the mean Tobin's $Q$ of non-innovative companies is less than 1, which indicates that the market might be undervaluing these companies. The mean Tobin's $Q$ of innovative companies exceeds 1 . The means of size are statistically significant as well, whereas the difference in growth is not statistically significant. It means that innovative companies are bigger compared to a non-innovative company.

Then, the authors of this study analyzed the relationship between innovation and company value using graphical method. Figure 3 represents the ratio of intangible assets and Tobin's $Q$ for Baltic listed companies from the period of 2005-2011.

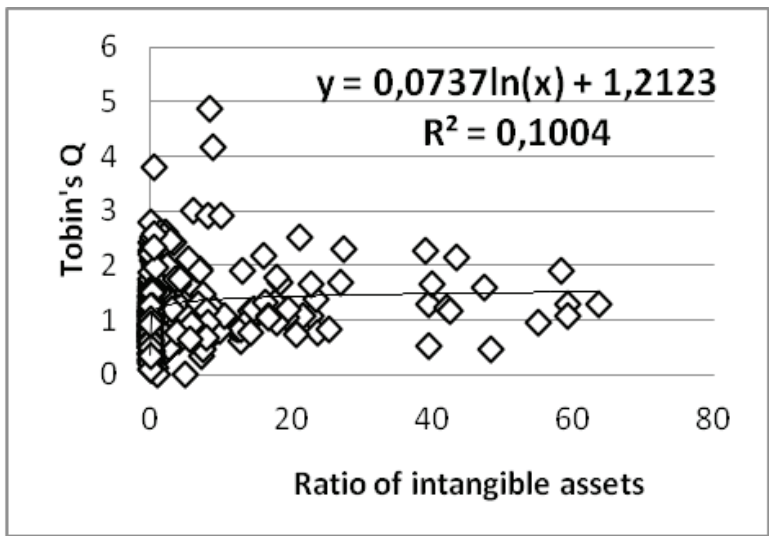

Figure 3. Tobin's $Q$ and ratio of intangible assets (\%) of Baltic listed companies, 2005-2011

Source: authors' construction based on the annual reports of the listed companies (Baltic Stock Exchange)

As can be seen (Figure 5), there is a slight positive relationship between innovation and company value. The relationship between company value and innovation is best described by logarithmic equation, since it achieved the highest $R^{2}$ of 0.1004 . In order words, $10 \%$ of the variability in company value could be explained by the level of innovation.

In addition all companies were categorized in groups, depending on their ratio of intangible assets and then the average Tobin's $Q$ was calculated for each group (Figure 4). A significant gap exists between companies with ratio of intangible assets $<1 \%$ and all other companies. If a company has a ratio of intangible assets of less than $1 \%$, its Tobin's $Q$ is around 1, however, if this ratio is more than $1 \%$, then the value of the company is significantly higher. 


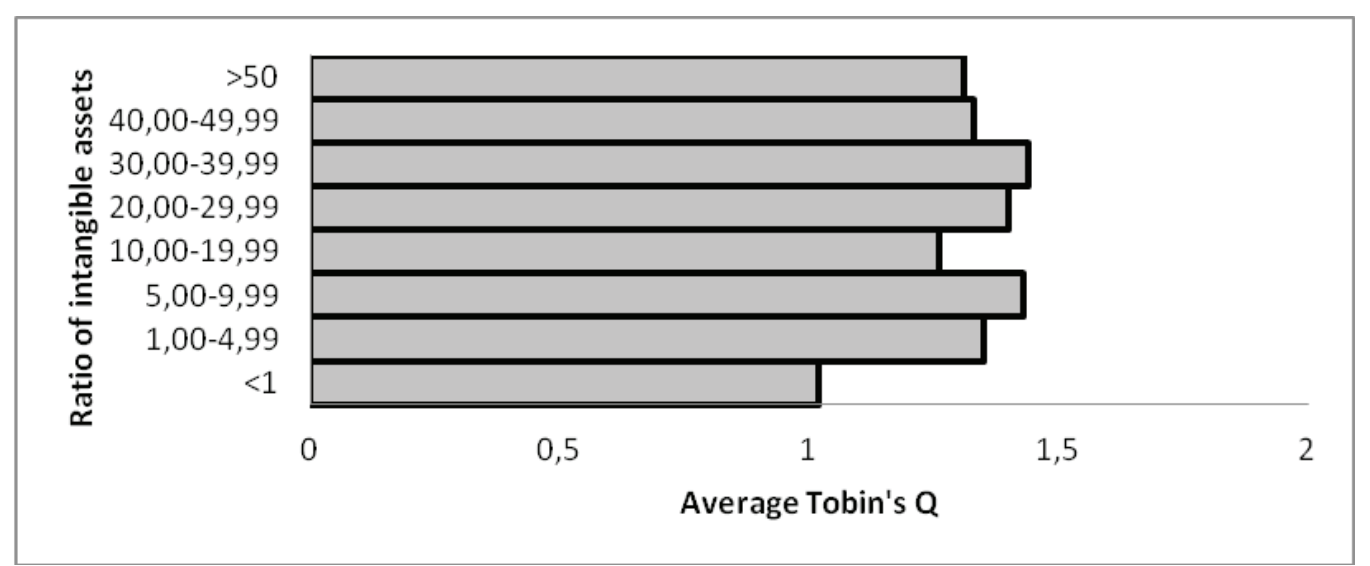

Figure 4. Ratio of intangible assets (\%) and average Tobin's $Q$ of Baltic listed companies, 2005-2011

Source: authors' calculations based on the annual reports of the listed companies (Baltic Stock Exchange)

As the next step, the authors analyzed the relationship between innovation and company value using correlation analysis. Table 3 provides the Pearson correlation matrix of the variables included in the study for the period of 2005-2011. Ratio of intangible assets is positively correlated with Tobin's $Q$ and size, while there is no significant correlation with growth. Once again, the conclusion can be made that company value increases with the level of innovation. In addition, bigger companies are more innovative than the smaller companies. Also, there are significant positive relationships between growth and Tobin's $Q$, as well as size and Tobin's $Q$ (companies are more valuable if they are bigger and have more growth opportunities).

Table 3. Pearson correlation matrix for Baltic listed companies, 2005-2011

\begin{tabular}{|c|c|c|c|c|}
\hline & Intangible assets & Growth & Tobin's Q & Size \\
\hline Intangible assets & 1 & & & \\
\hline Growth & $\begin{array}{l}0.022 \\
(0.662)\end{array}$ & 1 & & \\
\hline Tobin's Q & $\begin{array}{l}0.140 * * \\
(0.005)\end{array}$ & $\begin{array}{l}0.172 * * \\
(0.001)\end{array}$ & 1 & \\
\hline Size & $\begin{array}{l}0.148 * * \\
(0.003)\end{array}$ & \begin{tabular}{|l|}
0.038 \\
$(0.451)$
\end{tabular} & $\begin{array}{l}0.268 * * \\
(0.000)\end{array}$ & 1 \\
\hline
\end{tabular}

** Correlation is significant at the 0.01 level (2-tailed)

Source: authors' calculations based on the annual reports of the listed companies (Baltic Stock Exchange)

If one compares both subsamples (2005-2007 and 2008-2011, results are presented in Tables 4 and 5), several differences can be found. In the first period, significant correlations exist between ratio of intangible assets, growth and Tobin's $Q$, however in the second period growth is not statistically significant, whereas size is. Therefore, aconclusion can be made, that within the business cycle, relationships with innovation change. Another difference is that during the economic downturn the correlation coefficient (between Tobin's $Q$ and intangible assets) decreases in value, indicating that relationship gets weaker. 
Table 4. Pearson correlation matrix for Baltic listed companies, 2005-2007

\begin{tabular}{|c|l|l|l|l|}
\hline & \multicolumn{1}{|c|}{ Intangible assets } & \multicolumn{1}{c|}{ Growth } & Tobin's Q & Size \\
\hline Intangible assets & 1 & & & \\
\hline Growth & $\begin{array}{l}0.192^{*} \\
(0.013)\end{array}$ & 1 & & \\
\hline Tobin's Q & $\begin{array}{l}0.204^{*} \\
(0.008)\end{array}$ & $\begin{array}{l}0.167^{*} \\
(0.031)\end{array}$ & 1 & \\
\hline Size & $\begin{array}{l}0.151 \\
(0.050)\end{array}$ & $\begin{array}{l}0.116 \\
(0.134)\end{array}$ & $\begin{array}{l}0.379^{*} \\
(0.000)\end{array}$ & 1 \\
\hline
\end{tabular}

* Correlation is significant at the 0.05 level (2-tailed)

** Correlation is significant at the 0.01 level (2-tailed)

Source: authors' calculations based on the annual reports of the listed companies (Baltic Stock Exchange)

Table 5. Pearson correlation matrix for Baltic listed companies, 2008-2011

\begin{tabular}{|c|l|l|l|l|}
\hline & \multicolumn{1}{|c|}{ Intangible assets } & \multicolumn{1}{c|}{ Growth } & \multicolumn{1}{c|}{ Tobin's Q } & \\
\hline Intangible assets & 1 & & & \\
\hline Growth & $\begin{array}{l}-0.032 \\
(0.628)\end{array}$ & 1 & & \\
\hline Tobin's Q & $\begin{array}{l}0.187^{*} \\
(0.004)\end{array}$ & $\begin{array}{l}0.061 \\
(0.353)\end{array}$ & 1 & \\
\hline Size & $\begin{array}{l}0.139 * \\
(0.034)\end{array}$ & $\begin{array}{l}0.003 \\
(0.965)\end{array}$ & $\begin{array}{l}0.212^{* *} \\
(0.001)\end{array}$ & 1 \\
\hline
\end{tabular}

* Correlation is significant at the 0.05 level (2-tailed)

** Correlation is significant at the 0.01 level (2-tailed)

Source: authors' calculations based on the annual reports of the listed companies (Baltic Stock Exchange)

Finally, multiple regression analysis is performed (Table 6). The results from the regression model denote that the independent variables explain the variance in the value at a level of $16 \%$. The F-statistics prove the validity of the estimated model. Durbin-Watson d statistic is slightly within the "grey zone" (can not state definitely on the presence of autocorrelation problem), and no multicolinearity problem exists (VIF coefficients are around 1 and tolerance coefficients are greater than 0.5 in model).

Table 6. Regression model results for Baltic listed companies, 2005-2011

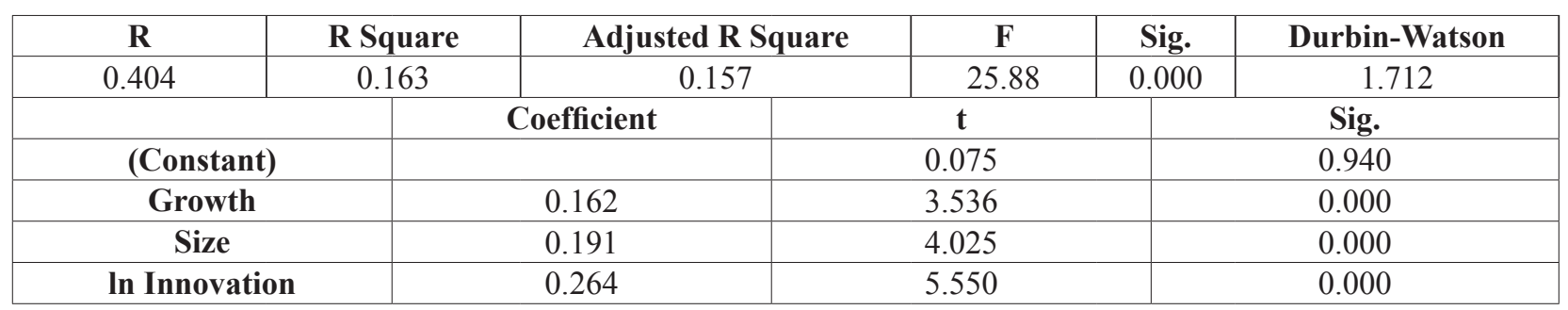

Source: authors' calculations based on the annual reports of the listed companies (Baltic Stock Exchange)

Regression equation is as follows:

$$
\text { Company value }=0.162 \text { Growth }+0.191 \text { Size }+0.264 \text { in Innovation }
$$

Once again, apositive relationship between company value and innovation is found. In addition, the coefficients of growth and size are statistically significant $(p<0.05)$.

Overall, based on correlation and multiple regression analyses, the authors of the paper conclude that the company value and the level of innovation are positively correlated, regardless of the business cycle. Size is a significant determinant as well; however, growth is the least significant factor. 
Conclusions and recommendations

The research covered Baltic listed companies for the period of 2005-2011, and analyzed the impact of innovation on company value. The study finds that:

- Innovative companies have a higher value and they are bigger, however differences in growth opportunities are not statistically significant for innovative and non-innovative companies.

- In innovative companies, there is a slight positive relationship between company value and the level of innovation; this relationship is best described by logarithmic equation.

- Within innovative companies, it was observed that higher company value is achieved if ratio of intangible assets exceeds $1 \%$.

- Using correlation analysis, it was concluded that innovative companies are most likely to be bigger in size.

- Significant relationships change within the business cycle (growth is a significant determinant during the economic boom, whereas size is a significant factor during the economic recession). This means that more innovative companies are growing faster during the economic boom, while bigger companies can afford to invest in innovation during the economic recession.

- The relationship between company value and innovation is weaker during the economic recession, if compared to economic boom.

- Based on correlation and multiple regression analyses, the authors conclude that the ratio of intangible assets is a significant determinant of company value, whereas size is a weaker factor. Growth is the least significant factor.

The authors of the paper recommend to companies to invest in innovation process, since it increases company value, especially if the ratio of intangible assets exceeds $1 \%$.

\section{References}

ACCA. (2007). Fresh Beginnings. Research and Development. Relevant to CAT Paper 6 and ACCA Qualification Papers F3, F7 and P2. Retrieved: http://www.accaglobal.com/content/dam/acca/global/PDF-students/2012/sa sep07_retallack.pdf. Access: 12.04.2013.

Aghion, P., Bond, S., Klemm, A., Marinescu, I. (2004). Technology and Financial Structure: Are Innovative Firms Different? Journal of European Economic Association, Vol. 2(2-3), p. 277-288.

Andrews, D., de Serres, A. (2012). Intangible Assets, Resource Allocation and Growth. A Framework for Analysis. OECD Economics Department Working Papers, No. 989. OECD Publishing.

Annavarjula, M., Mohan, R., Beldona, S. (2008). Technological Innovation and the Market Value of Firms. Communications of the IBIMA, Vol. 2.

Archibugi, D., Filippetti, A., Frenz, M. (2012). The Impact of the Economic Crisis on Innovation: Evidence from Europe. CIMR Research Working Paper Series. Working Paper, No. 5.

Ayyagari, M., Demirguc-Kunt, A., Maksimovic, V. (2011). Firm Innovation in Emerging Markets: The Role of Finance, Governance, and Competition. Journal of Financial and Quantitative Analysis, Vol. 46, No. 6, p. 1545-1580.

Bartoloni, E. (2013). Capital Structure and Innovation; Causality and Determinants. Empirica, Vol. 40, No. 2, p. 111151.

Belenzon, S., Patacconi, A. (2012). Innovation and Firm Value: An Investigation of the Changing Role of Patents, 1985-2007. Retrieved: https://faculty.fuqua.duke.edu/ sb135/bio/Belenzon\%20Patacconi\%20Chaning\%20 Role\%20of\%20Patents\%20July\%202012.pdf. Access: 17.04.2013.

Bistrova, J., Lace, N. (2011). Corporate Financial Strength Sustainability Post PO: Evidence from Baltic Equity Market. Economics and Management, Vol. 16, p. 1082-1088.

Chung, K. H., Pruitt, S. W. (1994). A Simple Approximation of Tobin's Q. The Journal of Financial Management Association, Vol. 23, No. 3, p. 70-74.

Coad, A., Rao, R. (2006). Innovation and Market Value: A Quantile Regression Analysis. Economics Bulletin, Vol. 15, No. 13, p. 1-10.

De Bes, F. T., Kotler, P. (2011).Winning at Innovation. The A-to-F Model. United Kingdom: Palgrave Macmillan. 
De Mel, S., McKenzie, D., Woodruff, C. (2009). Innovative Firms or Innovative Owners? Determinants of Innovation in Micro, Small, and Medium Enterprises. IZA Discussion Paper, No. 3962.

Dotzel, T., Shankar, V., Berry, L. (2013). Service Innovativeness and Firm Value. Journal of Marketing Research, Vol. 50, No. 2, p. 259-276.

Eurostat statistics. (2013). Retrieved: http://epp.eurostat.ec.europa.eu. Access: 13.04.2013.

Fagerberg, J. (2003). Innovation: A Guide to Literature. Presented at the Workshop "The many guises of innovation: what we have learnt and where we are heading". Ottawa, October 23-24.

Fagerberg, J., Fosaas, M., Sapprasert, K. (2012). Innovation: Exploring the Knowledge Base. Research Policy, Elsevier, Vol. 41, No. 7, p. 1132-1153.

Feeny, S., Rogers, M. (2001). Innovation and Performance: Benchmarking Australian Firms. Melbourne Institute Working Paper, No. 7/01.

Global Innovation Index 2012 Edition. Retrieved: http://www.globalinnovationindex.org/gii/. Access: 12.04.2013.

Gomez-Gonzalez, J. E., Rincon, C. E. L., Rodriguez, K. J. L. (2012). Does the Use of Foreign Currency Derivatives Affect Firm's Market Value? Evidence from Colombia. Emerging Markets Finance \& Trade, Vol. 48, No. 4, p. 50-66.

Hall, B. (1998). Innovation and Market Value. Prepared for the NIESR conference on Productivity and Competitiveness. London, February 5-6.

Hsu, H. (2011). Institutional Ownership, Capital Structure and R\&D Investment. 2011 International Conference on Economics and Finance Research. IPEDR, Vol. 4. IACSIT Press, Singapore.

Huhtala, J. (2011). Market Orientation, Innovation Capability and Business Performance: Insights from Different Phases of the Business Cycle. eThesis. Retrieved: http://epub.lib.aalto.fi/en/ethesis/id/12518. Access: 17.04.2013.

International Accounting Standards. Retrieved: http:/www.iasplus.com/en/standards/standard37. Access: 12.04.2013.

Jesilevska, S. (2012). Statistical Aspects of Collecting Innovation Data. Journal of Economics and Management, Vol. 1, p. 54-66.

Jin, Y., Jorion, P. (2006). Firm Value and Hedging: Evidence from U.S. Oil and Gas Producers. The Journal of Finance, Vol. 61, No. 2, p. 893-919.

Kleinknecht, A., Montfort, K., Brouwer, E. (2002). The Non-trivial Choice between Innovation Indicators. Economics of Innovation and New Technology, Vol. 11, No. 2, p. 109-121.

Kogan, L., Papanikolaou, D., Seru, A., Stoffman, N. (2012). Technological Innovation, Resource Allocation and Growth. NBER Working Paper, No. 17769.

Kraft, K., Czarnitzki, D. (2002). Measuring the Impact of Innovation on Firm Value: A New Approach. ZEW Discussion Papers, No. 02-73.

Kuniy, M., Basso, L. F. C., Kimura, H. (2010). Innovation Strategy and Capital Structure of Brazilian Companies. Retrieved: http://papers.ssrn.com/sol3/papers.cfm?abstract_id=1567594. Access: 17.04.2013.

Li, E. X. N., Liu, L. X. L. (2012). Intangible Assets and Cross - Sectional Stock Returns: Evidence from Structural Estimation. Under review in Management Science.

Linderberg, E. B., Ross, S. A. (1981). Tobin's Q Ratio and Industrial Organization. Journal of Business, Vol. 54, No. 1, p. 1-32.

Lopez-Garcia, P., Montero, J. M., Moral-Benito, E. (2012). Business Cycles and Investment in Intangibles: Evidence from Spanish Firms. Banco de Espana Working Paper, No. 1219.

NASDAQ OMX Baltic. (2013). Retrieved: http://www.nasdaqomxbaltic.com. Access: 14.04.2013.

Shin, M., Kim, S. (2011). The Effects of R\&D Expenditure on the Firm Value: Evidence from Korean Small and Medium Sized Enterprises. Journal of Finance and Accountancy, Vol. 7, p. 1-20.

Sorescu, A., Spanjol, J. (2008). Innovation's Effect on Firm Value and Risk: Insights from Consumer Packaged Goods. Journal of Marketing, Vol. 72, p. 114-132.

Statement of Financial Accounting Standards, No. 142. Goodwill and Other Intangible Assets. Retrieved: http://www. fasb.org/pdf/fas142.pdf. Access: 12.04.2013.

Sundbo, J. (1997). Management of Innovation in Services. The Services Journal, Vol. 17, No. 3, p. $432-455$.

Tobin, J. (1969). A General Equilibrium Approach to Monetary Theory. Journal of Money, Credit and Banking, Vol. 1, No. 1, p. 15-29.

Wernerfelt, B., Montgomery, C. A. (1998). Tobin's Q and the Importance of Focus in Firm Performance. The American Economic Review, Vol. 78, No. 1, p. 246-250.

This work has been supported by the European Social Fund within the project "Support for Doctoral Studies at University of Latvia". 


\section{INOVACIJOS IR BENDROVÉS VERTÉ: BALTIJOS ŠALIŲ PATIRTIS}

Irina Berzkalne, Elvira Zelgalve

Latvijos universitetas (Latvija)

\section{Santrauka}

Inovacijos yra konkurencingumo pagrindas. Kartu pagrindinis vadovo uždavinys yra savininkų turto maksimizavimas, todèl svarbu tyrinèti inovacijų ir bendrovès vertès santykị. Šio tyrimo tikslas - ištirti inovaciju poveiki organizacijos vertei. Tiriamos Baltijos šaliu bendrovės, veikusios 2005-2011 metu laikotarpiu. Tyrimas parodè, kad inovatyvių bendrovių verte yra didesnè, didesnès ir jos pačios. Nustatyta, kad didesnè bendrovès vertè pasiekiama, jei nematerialiu išteklių dalis viršija $1 \%$. Taikant koreliaciją ir regresinę analizę, nustatyta, kad inovacijos yra svarbi organizacijos vertès determinantè, organizacijos dydis yra silpnesnis veiksnys, o augimas - pats silpniausias veiksnys. Straipsnio autorès rekomenduoja bendrovèms investuoti i inovacijos procesą, nes tai didina jų vertę, ypač jei nematerialiu išteklių dalis viršija $1 \%$.

PAGRINDINIAI ŽODŽIAI: bendroves vertè, inovacijos, nematerialūs ištekliai, tyrimai ir plètra, Tobino $Q$.

JEL KLASIFIKACIJA: G32, O16, O31 